\title{
Analysis of the Serum Components in Acute Period After Subarachnoid Hemorrhage
}

\section{Subaraknoid Kanama Sonrası Akut Dönemde Serum Bileşenleri Analizi}

\author{
Tomasz TYKOCKI ${ }^{1}$, Kacper KOSTYRA², Krzysztof BOJANOWSKI², Bogusław KOSTKIEWICZ² \\ ${ }^{1}$ Institute of Psychiatry and Neurology, Department of Neurosurgery, Warsaw, Poland \\ ${ }^{2}$ Central Clinical Hospital Ministry of Interior in Warsaw, Department of Neurosurgery, Poland
}

Corresponding Author: Tomasz TYKOCKI / E-mail: ttomasz@mp.pl

\begin{abstract}
AIM: Multi-profile monitoring of various blood serum factors during acute subarachnoid haemorrhage (SAH) is crucial for successful treatment. The aim of the study is to evaluate the serum concentration of different blood factors in the acute period of SAH.

MATERIAL and METHODS: 31 patients with confirmed aneurysmal SAH were enrolled in a prospective study. The concentrations of the following serum compounds were assessed on the day of admission and reassessed after 5 days: lipids profile, cardiac functionality enzymes and markers, electrolytes, osmolality, CRP (C-reactive protein), glucose, creatinine, urine.

RESULTS: The mean level of high-density lipoprotein (HDL) changed significantly from $43.9 \pm 23.9 \mathrm{mg} / \mathrm{dL}$ to $27.5 \pm 19,8 \mathrm{mg} / \mathrm{dL}$, $\mathrm{p}=0,013$ (mean dif. $16.5 \pm 14,1 \mathrm{mg} / \mathrm{dL} ; 37,3 \%$ ). Concentration of low-density lipoprotein (LDL) decreased by $28.6 \%$ (mean dif. 26.78 $\pm 61.32 ; p=0.047$ ). Values of triglicerydes and total cholesterol did not differ significantly between the initial evaluations and these repeated after 5 days. The overall serum ions $\left(\mathrm{Na}^{+}, \mathrm{K}^{+}, \mathrm{Mg}^{2+}, \mathrm{Ca}^{2+}\right)$ concentrations and osmolality did not differ significantly between the initial measurements and after 5 days from $\mathrm{SAH}$. The only mean value that appeared to be substantially increased at initial measurement was NT-proBNP and reached $1928.8 \pm 4952 \mathrm{pg} /$ $\mathrm{ml}$, this value dropped down to $392.87 \pm 1147.9 \mathrm{mg} / \mathrm{ml}$ after 5 days (mean dif. $1535.96 \pm 4808.76 \mathrm{pg} / \mathrm{ml} ; 79,6 \% ; \mathrm{p}=0.247$ ). CRP increased over 2 fold after 5 days up to $29.267 \pm 28.614 \mathrm{mg} / \mathrm{L}$ (mean dif. $16.06 \pm 34.05 \mathrm{pg} / \mathrm{L} ; 121.6 \% ; \mathrm{p}=0.028$ ). At 5 -day follow up hematocrit dropped to $33.38 \pm$ $3.81 \%$ from the initial value of $39.63 \pm 2,56 \%(p=0.02)$.
\end{abstract}

CONCLUSION: This study showed a significant decrease in the serum level of LDL and HDL, while triglycerides were moderately heightened. Routine monitoring of lipid profile and statin administration at the early stage of SAH is recommended.

KEYWORDS: Subarachnoid haemorrhage, Aneurysm, Lipids, Electrolytes, Cardiac enzymes

Öz

AMAÇ: Akut subaraknoid kanama (SAK) sırasında çeşitli kan serumu faktörlerinin çoklu profille izlenmesi başarılı bir tedavi için çok önemlidir. Çalışmanın amacı, SAK'nın akut döneminde farklı kan faktörlerinin serum konsantrasyonunu değerlendirmektir.

YÖNTEM ve GEREÇLER: Bu prospektif çalışmaya teyit edilmiş anevrizmal SAK durumu olan 31 hasta alındı. Aşağıdaki serum bileşiklerin konsantrasyonları hastaneye yatma gününde ve 5 gün sonra değerlendirildi: lipid profili, kardiyak fonksiyon enzimleri ve belirteçleri, elektrolitler, ozmolalite, CRP (C-reaktif protein), glukoz, kreatinin. Ayrıca idrar tahlili yapıldı.

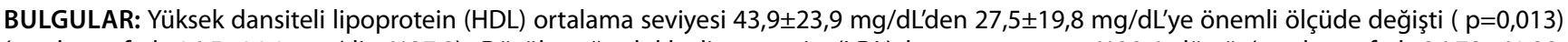

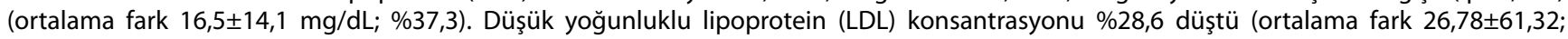
$\mathrm{p}=0,047)$. Trigliserid ve total kolesterol değerleri açısından ilk değerlendirme ve 5 gün sonra tekrarlananlar arasında anlamlı farklılık yoktu. Genel serum iyon $\left(\mathrm{Na}^{+}, \mathrm{K}^{+}, \mathrm{Mg}^{2+}, \mathrm{Ca}^{2+}\right)$ konsantrasyonları ve ozmolalite açısından ilk değerlendirme ile SAK'tan 5 gün sonra tekrarlananlar arasında anlamlı farklılık yoktu. İlk ölçümde önemli ölçüde artmış gibi görünen tek ortalama değer NT-proBNP idi ve 1928,8 49952 pg/ml'ye

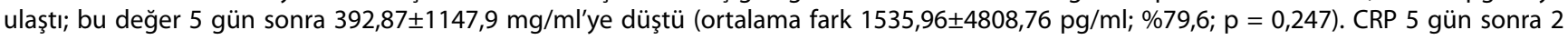
katına yani $29,267 \pm 28,614 \mathrm{mg} / \mathrm{L}$ 'ye çıktı (ortalama fark 16,06 $\pm 34,05 \mathrm{pg} / \mathrm{L} ;$ artış \%121,6; $\mathrm{p}=0.028$ ). Hematokrit 5 . gün takibinde ilk değer olan

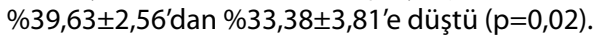

SONUÇ: Çalışmada trigliserid orta derecede artarken, LDL ve HDL serum seviyesinde önemli bir düşüş görüldü. SAK'nın erken aşamasında lipid profilinin rutin takibi ve statin uygulanması önerilmektedir.

ANAHTAR SÖZCÜKLER: Subaraknoid kanama, Anevrizma, Lipidler, Elektrolitler, Kardiyak enzimler

\section{INTRODUCTION}

Fluid and electrolyte disturbances are frequently observed during the acute and subacute period after subarachnoid hemorrhage (SAH). Serum sodium concentration and fluid balance are frequently abnormal in SAH, occurring in up to
$50 \%$ of patients $(8,37)$, hyper-and hyponatremia are associated with persistent neurological deficits and high mortality $(2,10,15)$. Hypomagnesemia and hypokalemia are observed in one third of cases (40). Serum and cerebrospinal fluid levels of C-reactive protein (CRP) are significantly elevated in patients 
with vasospasm and strongly associated with poor clinical outcome (9). Most patients with $\mathrm{SAH}$ become relatively hemodiluted, nevertheless recent studies have questioned whether intentional lowering of the hematocrit to this level is actually beneficial $(7,30)$.

Many serum factors might be associated with the prognosis of the early post-SAH medical course of patients. Considerable expectations are related with the statin treatment in the prevention of vasospasm and delayed ischemic deficits. Besides, hyperglycemia was observed in $30 \%$ of SAH patients and was found to be a predictor of poor functional outcome and mortality at 3 months (23).

Abnormalities in the serum level of cardiac biomarkers are often encountered after SAH. Troponin I (Tn-I) is elevated in approximately $20-30 \%$ of patients with the peak level within 1-2 days from the onset of SAH $(21,24)$. Serum level of the brain natriuretic peptide (BNP) was also found to be increased soon after $\mathrm{SAH}$ and returning to baseline in 1 to 2 weeks (34). Increased BNP level is a predictor of worse neurologic outcomes and early in-hospital mortality (36).

In the light of the abovementioned data authors prepared a prospective study to evaluate the serum concentration of different blood factors in the acute period of SAH. 5-day follow up was proposed to investigate the early post $\mathrm{SAH}$ dynamics of the serum components.

\section{METHODS}

This is a prospective study from a cohort of patients with confirmed aneurysmal SAH admitted to the Department of Neurosurgery between 2011 and 2013. Patients were enrolled in the study within 48 hours from the onset of $\mathrm{SAH}$. Informed written consent from the patient or family was obligatory before enrolment in the study. The diagnosis of SAH was based on the computed tomography. Patients underwent cerebral angiography or angio-CT to identify the aneurysm morphology and location. Cases with any heart disease such as cardiomyopathy, prior myocardial infarction or atrial fibrillation were not included. All aneurysms were treated with surgical clipping within the first 48 hours from admission and postoperatively managed in the neurointensive care unit. Standard medical management included intravenous infusion of isotonic saline and colloids (Hydroxyethyl starch, HAES) for the purpose of volume expansion. In patients with hypotension and intracranial hypertension continuous infusion of norepinephrine was used. Nimodipine was administrated obligatory intravenous or orally. Fluid and sodium balance were calculated daily. The mean arterial blood pressure was maintained at a mean arterial pressure of 100 to $110 \mathrm{mmHg}$. Atorvastatin was administrated at dose $80 \mathrm{mg} /$ day from the day of admission. Follow-up CT scans were typically performed to evaluate unexplained declines in neurological status. The neurological status was graded according to the World Federation of Neurosurgical Societies (WFNS) scale and the radiological severity of SAH was classified in the Fisher score. Clinical data were collected from the patient, family interviews and the medical record.
Blood samples were collected in EDTA tubes, centrifuged, and stored at $-70^{\circ} \mathrm{C}$. The concentrations of the following serum compounds were assessed on the day of admission and reassessed after 5 days: lipids profile (low density lipoprotein cholesterol LDL, high density lipoprotein cholesterol-HDL, triglycerides-TG, total cholesterol-TCh), cardiac functionality enzymes and markers ( $T n, M B$ fraction of creatine kinase$\mathrm{CK}-\mathrm{MB}$, creatine kinase-CK, N-terminal pro-brain natriuretic peptide NT - proBNP, asparate transaminase-AST) electrolytes $\left(\mathrm{Na}^{+}, \mathrm{K}^{+}, \mathrm{Mg}^{2+}, \mathrm{Ca}^{2+}\right.$ ) osmolality, CRP (C-reactive protein), glucose, creatinine, urine.

All the results were statistically analysed using the computer software Statistica 10, StatSoft, Tulsa, OK, US. Statistical significance was assumed for $p<0.05$. A paired t-test was performed to establish the significant differences between repeated measurements of the serum compounds.

\section{RESULTS}

The study included 31 patients with a mean age of 53.6 \pm 15.2 years. There were 19 females. The functional impairment at discharge was evaluated with the modified Rankin scale ( $\mathrm{mRS}$ ) and the scores were as follows: $\mathrm{mRS} 0$ in 4 patients; I in 6, II in 4; III in 9; IV in 4: V in 4; and VI in 0 patients. The overall serum ions $\left(\mathrm{Na}^{+}, \mathrm{K}^{+}, \mathrm{Mg}^{2+}, \mathrm{Ca}^{2+}\right)$ concentrations did not differ significantly between the initial measurements and after 5 days from $\mathrm{SAH}$. The mean serum level of $\mathrm{Na}^{+}$increased after 5 days above the upper reference value (160.84 \pm 207.8464 $\mathrm{mmol} / \mathrm{L})$, whereas the mean concentration of $\mathrm{Ca}^{2+}$ declined to $1.627 \pm 0.9122 \mathrm{mmol} / \mathrm{L}$. Osmolality levels changed from $274 \pm 99$ to $310 \pm 35 \mathrm{mOsm} / \mathrm{kg} \mathrm{H}_{2} \mathrm{O}$. 5-day difference was 47.6 \pm $35.7 \mathrm{mOsm} / \mathrm{kg} \mathrm{H} 2 \mathrm{O}$ (13\%). The detailed results were presented in Table I. The panel of cardiac functionality enzymes and markers included: Tn, CK-MB, CK, AST and NT - proBNP. The only mean value that appeared to be substantially increased at initial measurement was NT-proBNP and reached $1928.8 \pm$ $4952 \mathrm{pg} / \mathrm{ml}$, this value dropped down to $392.87 \pm 1147.9 \mathrm{pg} /$ $\mathrm{ml}$ after 5 days (mean dif. $1535.96 \pm 4808.76 \mathrm{pg} / \mathrm{ml} ; 79.6 \%$; $\mathrm{p}$ $=0.247$ ). None of other cardiac factors results deviated from the corresponding reference values, both within 24 hours form SAH onset and after 5 days (Table II). These values did not differ substantially between the initial and repeated measurements. In one case with enormous elevated level of NT-proBNP (17897 pg/ml), symptoms of heart failure were observed with the ejection fraction below $50 \%$ and regional wall motion abnormalities.

The lipid profile included the serum concentration of $L D L$, $\mathrm{HDL}$, TCh and TG. The mean level of HDL changed significantly from $43.9 \pm 23.9 \mathrm{mg} / \mathrm{dL}$ to $27.5 \pm 19.8 \mathrm{mg} / \mathrm{dL}, \mathrm{p}=0.013$ (mean dif. $16.5 \pm 14.1 \mathrm{mg} / \mathrm{dL} ; 37.3 \%)$. Concentration of LDL decreased by $28.6 \%$ (mean dif. 26.78 $\pm 61.32 ; p=0.047$ ) (Figure 1). Values of TG and TCh did not differ significantly between the initial evaluations and these repeated after 5 days. The first measurement of CRP level reached $13.212 \pm 20.2511 \mathrm{mg} / \mathrm{L}$ and increased over 2 fold after 5 days up to $29.267 \pm 28.614 \mathrm{mg} / \mathrm{L}$ (mean dif. $16.06 \pm 34.05 \mathrm{mg} / \mathrm{L} ; 121.6 \% ; \mathrm{p}=0.028$ ). At 5 -day follow up HCT dropped to $33.38 \pm 3.81 \%$ from the initial value of $39.63 \pm 2.56 \%(p=0.02)$ (Figure 2$)$. 
Table I: Mean Values of the Selected Serum Compounds Assessed Within 24 Hours from the Admission and at 5-Day Follow Up

\begin{tabular}{|c|c|c|c|c|c|c|c|c|c|}
\hline \multicolumn{3}{|c|}{ Admission Day } & \multicolumn{3}{|c|}{ At 5-Day Follow up } & \multirow[b]{2}{*}{$\begin{array}{c}\text { Mean } \\
\text { Difference }\end{array}$} & \multirow[b]{2}{*}{ SD } & \multirow[b]{2}{*}{$\mathbf{p}$} & \multirow[b]{2}{*}{ Unit } \\
\hline & Mean & SD & & Mean & SD & & & & \\
\hline Osmolality & 274.41 & 99.58 & Osmolality 1 & 310.09 & 16.50 & 47.60 & 35.68 & 0.103 & $\begin{array}{c}\mathrm{mOsm} / \mathrm{kg} \\
\mathrm{H}_{2} \mathrm{O}\end{array}$ \\
\hline Hematocrit & 39.63 & 3.80 & Hematocrit 1 & 33.38 & 2.50 & 6.24 & 1.20 & $0.02^{*}$ & $\%$ \\
\hline $\mathrm{Na}^{+}$ & 138.35 & 4.95 & $\mathrm{Na}^{+} 1$ & 160.84 & 207.85 & 22.49 & 20.61 & 0.589 & $\mathrm{mmol} / \mathrm{L}$ \\
\hline $\mathrm{Ca}^{2+}$ & 1.97 & 0.68 & $\mathrm{Ca}^{2+} 1$ & 1.63 & 0.91 & 0.34 & 1.26 & 0.426 & $\mathrm{mmol} / \mathrm{L}$ \\
\hline $\mathrm{K}^{+}$ & 3.97 & 0.36 & $\mathrm{~K}^{+} 1$ & 3.55 & 1.47 & 0.42 & 1.49 & 0.23 & $\mathrm{mmol} / \mathrm{L}$ \\
\hline $\mathrm{Mg}^{2+}$ & 1.79 & 0.64 & $\mathrm{Mg}^{2+1}$ & 1.53 & 0.87 & 0.27 & 1.19 & 0.508 & $\mathrm{mmol} / \mathrm{L}$ \\
\hline CRP & 13.21 & 20.25 & CRP 1 & 29.27 & 28.61 & 16.06 & 34.05 & $0.028^{*}$ & $\mathrm{mg} / \mathrm{L}$ \\
\hline Glucose & 104.78 & 65.00 & Glucose 1 & 87.18 & 65.45 & 17.60 & 88.40 & 0.146 & $\mathrm{mg} / \mathrm{dL}$ \\
\hline Creatinine & 0.82 & 0.39 & Creatinine 1 & 0.74 & 0.51 & 0.08 & 0.62 & 0.41 & $\mathrm{mg} / \mathrm{dL}$ \\
\hline Urine & 25.67 & 12.37 & Urine 1 & 21.00 & 15.61 & 7.67 & 16.70 & 0.16 & $\mathrm{mg} / \mathrm{dL}$ \\
\hline LDL & 93.37 & 51.68 & LDL1 & 66.59 & 43.93 & 26.78 & 14.10 & $0.047^{*}$ & $\mathrm{mg} / \mathrm{dL}$ \\
\hline HDL & 43.96 & 23.92 & HDL1 & 27.46 & 19.75 & 16.51 & 61.32 & $0.013^{*}$ & $\mathrm{mg} / \mathrm{dL}$ \\
\hline Total cholesterol & 136.39 & 68.11 & Total cholesterol 1 & 101.56 & 71.13 & 34.80 & 99.70 & 0.157 & $\mathrm{mg} / \mathrm{dL}$ \\
\hline Triglicerides & 78.41 & 39.40 & Triglicerides 1 & 91.14 & 63.69 & 12.72 & 74.13 & 0.332 & $\mathrm{mg} / \mathrm{dL}$ \\
\hline
\end{tabular}

SD - standard deviation. CRP-C-reactive protein. LDL - low density lipoprotein cholesterol. HDL- high density lipoprotein cholesterol. * - difference statistically significant.

Table II: Mean Values of the Cardiac Enzymes and Markers Assessed within 24 Hours from the Admission and at 5-Day Follow Up

\begin{tabular}{|c|c|c|c|c|c|c|c|c|c|}
\hline \multicolumn{3}{|c|}{ Admission Day } & \multicolumn{3}{|c|}{ At 5-Day Follow up } & \multirow[b]{2}{*}{$\begin{array}{c}\text { Mean } \\
\text { Difference }\end{array}$} & \multirow[b]{2}{*}{ SD } & \multirow[b]{2}{*}{$\mathbf{p}$} & \multirow[b]{2}{*}{ Unit } \\
\hline & Mean & SD & & Mean & SD & & & & \\
\hline NT - proBNP & 1748.72 & 4534.70 & NT - proBNP 1 & 389.39 & 1103.79 & 1359.33 & 4808.76 & 0.247 & $\mathrm{pg} / \mathrm{mL}$ \\
\hline CK-MB & 17.86 & 8.27 & CK-MB 1 & 11.59 & 8.12 & 6.27 & 14.32 & 0.527 & ug/L \\
\hline Troponin & 0.08 & 0.27 & Troponin 1 & 0.10 & 0.29 & 0.08 & 0.24 & 0.278 & ug/L \\
\hline CK & 183.39 & 282.43 & CK 1 & 133.91 & 240.04 & 49.00 & 414.90 & 0.554 & IU/L \\
\hline AST & 27.67 & 22.95 & AST 1 & 31.41 & 57.84 & 3.74 & 65.02 & 0.904 & IU/L \\
\hline
\end{tabular}

SD - standard deviation; NT - proBNP - N- terminal pro-brain natriuretic peptide; CK-MB - MB fraction of creatine kinase; $\boldsymbol{A S T}$ - asparate transaminase; CK-creatine kinase.

\section{DISCUSSION}

The medical approach to patients with aneurysmal SAH is one of the major challenges in neurosurgical perioperative care. The recommended triple- $\mathrm{H}$ therapy, despite the absence of large randomized trials, has been postulated to be the optimal management of SAH patients. However, next to the hemodynamic therapy, multi-profile monitoring and treatment of the imbalance of various blood serum factors during acute $\mathrm{SAH}$ is invaluable for the success of the therapy. In this study, selected serum compounds were evaluated in this crucial period of acute SAH to provide an overview and evaluate the dynamics of serum compounds in a patient cohort.

The standard hemodynamic augmentation therapy (triple $\mathrm{H}$; hypervolemia, hypertension, and hemodilution) has recently shifted the focus to the maintenance of euvolemia and induced hypertension. Euklund et al. compared isovolemic and hypervolemic hemodilution by lowering the hematocrit from 36 to $28 \%$ and reported that hemodilution to a hematocrit value of $28 \%$ was not beneficial in patients with cerebral vasospasm (7). Our results showed moderate hemodilution of $33 \%$ and the reduction of initial hematocrit of $39 \%$ was mostly due to the intensive hypervolemic therapy.

The serum concentrations of ions $\left(\mathrm{Na}^{+}, \mathrm{K}^{+}, \mathrm{Mg}^{2+}, \mathrm{Ca}^{2+}\right)$ did not differ significantly between the initial measurements and after 5 days from $\mathrm{SAH}$. However, the magnesium level was postulated to have a neuroprotective impact on prevention of symptomatic vasospasm and for a favourable outcome after $\mathrm{SAH}$. Results from a phase 3 trial (Intravenous Magnesium sulphate for Aneurysmal Subarachnoid Hemorrhage (IMASH) 


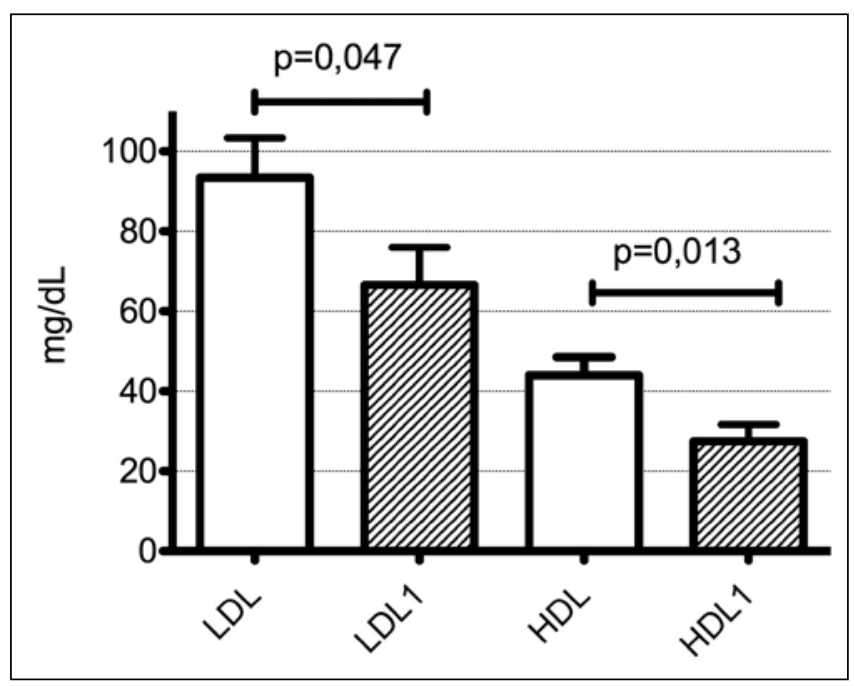

Figure 1: Column bar graph presenting the results of low and high-density lipoprotein at baseline ant at 5-day follow up.

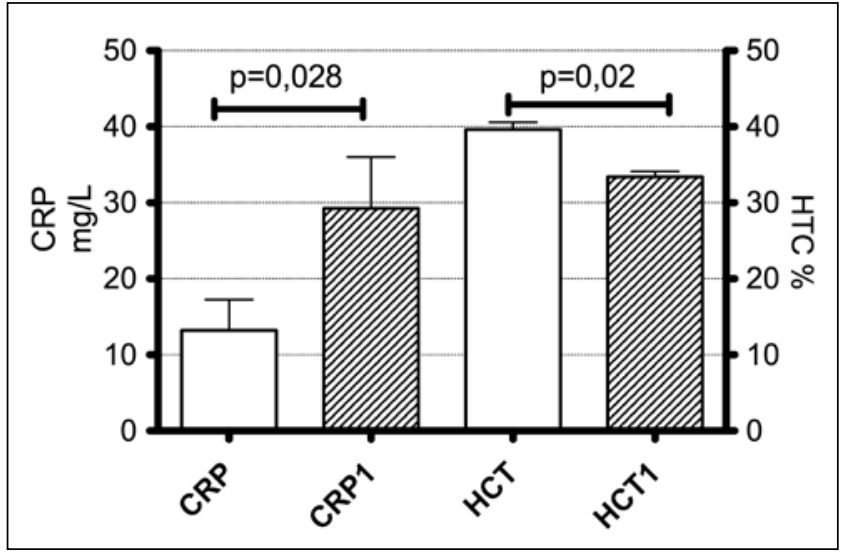

Figure 2: Column bar graph presenting the results of $C$-reactive protein and hematocrit at baseline ant at 5-day follow up.

did not support any clinical benefit from magnesium infusion over placebo in SAH $(42,43)$.

Data from the Columbia University SAH Outcomes Project proved the correlation between a higher hemoglobin level and improved outcomes after SAH at 14 days or at discharge and 3 months (20). Contrary, perioperative blood transfusion is potentially harmful in patients with SAH and leads to increased risk of cerebral ischemia, developing angiographic cerebral vasospasm and worse modified Rankin score at discharge $(20,29)$.

The serum concentration of lipids is postulated to be associated with the risk of the aneurysm rupture and postsubarachnoid hemorrhage vasospasm. Nonetheless, different studies present divergent conclusions on the role of lipids. Large population-based studies $(11,4,44)$ have advocated the role of hypercholesterolemia as a possible risk factor of $\mathrm{SAH}$. On the contrary, however, a pooled analysis did not confirm hypercholesterolemia as a predictor of SAH (32). The protective role of statins is based on the upregulation of the endothelial nitric oxide synthase, reduction of low-density lipoprotein (LDL), and modulation of the anti-inflammatory and endothelial activation response after statin administration (25). The recent reports present contrary findings. Whilst a meta-analysis reported no evidence for the clinical benefit (38), some other randomized trials prove approving outcomes (35). The on-going large phase 3 trial SimvasTatin in Aneurysmal Subarachnoid Hemorrhage (STASH) hopefully will convincingly answer this dilemma.

In the study of Tokuda et al. the median serum level of total cholesterol was $161 \mathrm{mg} / \mathrm{dl}$ in patients with SAH, and $209 \mathrm{mg} /$ $\mathrm{dl}$ in controls (33). Median serum triglycerides were $95 \mathrm{mg} /$ $\mathrm{dl}$ in SAH and $122 \mathrm{mg} / \mathrm{dl}$ in controls. They also found that a serum total cholesterol of more than $200 \mathrm{mg} / \mathrm{dl}$ and serum triglycerides of more than $150 \mathrm{mg} / \mathrm{dl}$ were independent protective factors for SAH. Surprisingly, the conclusion form this study was that higher values of both serum cholesterol and triglycerides may be inversely associated with the occurrence of SAH. In another study no association of any serum lipid and the risk of SAH was found, except a negative association of $\mathrm{HDL}$ cholesterol in participants younger than 50 years of age (28). The results of serum lipids concentrations from this study have shown decreased values of HLD, LDL, and TCh after 5 days comparing to the baseline. The change was significant for LDL, HDL and was estimated as $29 \%$ and $37 \%$ respectively. TG levels decreased moderately by $16 \%$ at the 5 th day. Probably two factors might caused the change in the serum lipid profile; 1) administration of atorvastatin and 2) severe metabolic stress. Although, the full lipid modulating effect can be seen as early as several weeks after starting statins, some studies have shown that a significant reduction in LDL and TCh after 7 days of atorvastatin therapy $(18,25)$. Therefore a significant shift in the lipid profile after 5 days found in this study might be due to the atorvastatin administration. Cumulative review of the randomised, double blind controlled trials reporting to the efficacy of the atorvastatin in hypercholesterolemia showed the mean reduction of LDL by $36 \%$ and triglycerides by $17 \%(6,41)$. These results are comparable with our observations. Metabolic shock is another factor alongside the statins, affecting the sudden transition of serum lipids level after SAH. The shifts in serum lipids concentration in the early period after severe trauma probably results from the increased catabolism, higher availability of free fatty acids, oversecretion of catecholamines, cytokines, tumor necrosis factors or interferons $(13,35)$. It has been proven that the lipid profile may significantly change shortly after burn injury where serum TCh level decreased by $26 \%$ and HDL by $52 \%$ in the first week, while TG was slightly raised in one week and then decreased by $18.6 \%$ compared to normal subjects (27).

CRP level may predict the neurological course after SAH. Interestingly, the surgically treated group demonstrated higher levels of CRP in serum and CSF compared with those who were treated endovascularly. There is some discrepancy about the predictive value of CRP. Fountas et al. reported 
that elevated CRP levels in serum and CSF were associated with increased incidence of angiographic vasospasm (9). Additionally, the elevated CSF and serum CRP were associated with worse clinical outcome, as expressed in Glasgow Outcome and mRS scores. On the other hand, Juvela et al. concluded that CRP levels correlate with outcome but do not predict delayed cerebral ischemia or infarction after SAH (12). Generally the serum values of CRP rise in the acute period of SAH and tend to be higher in CSF than in serum. CRP levels increased significantly between the day of hospital admission from $11.4 \mathrm{mg} / \mathrm{L}$ to $19.8 \mathrm{mg} / \mathrm{L}$ during the second week (12). The CRP serum level increased almost 3 fold after 5 days in comparison to the initial level of $4 \mathrm{mg} / \mathrm{L}$, while the baseline level of CRP in CSF was $10 \mathrm{mg} / \mathrm{L}$ and doubled within 5 days (9). This is consistent with results from this study where serum CRP level changed from $13 \mathrm{mg} / \mathrm{L}$ to $29 \mathrm{mg} / \mathrm{L}$ and the difference was statistically significant. CRP is of course a nonspecific factor for SAH and its increase may be due to other conditions, in particular inflammation of various origin.

The prevalence of SAH-induced cardiac dysfunction, often named neurogenic stunned myocardium (NSM), has been estimated as at least $20-30 \%$ (1). The pathogenesis of the $\mathrm{SAH}$-induced NSM is based on the catecholamine oversecretion. An increased plasma level of troponine was found to be a sensitive and specific indicator of neurogenic stunned myocardium, while creatine kinase-MB is a superior marker of myocardial infarction (14). The elevated sympathetic tone leads to the opening of cardiomyocyte calcium channels through the activation of $\beta 1$-adrenergic receptors resulting in myocardial depression (3).

Cardiac injury may be immediately evident or develop within hours after aneurysmal rupture. The timing of recovery in $\mathrm{SAH}$-induced left ventricle dysfunction can be quite variable, with improvement in ejection fraction ranging from days to weeks (3-42 days) (19,39).

Recent results provide indirect evidence that the heart is the primary source of elevated BNP levels after SAH. Nakamura et al. reported a positive correlation between BNP and pulmonary extravascular water content in SAH patients with consciousness disturbance (22).

The overload on the left ventricle or atrium causing increased pulmonary capillary pressure begins immediately after SAH onset and results in cardiopulmonary edema. Elevated BNP level indicates systolic and diastolic dysfunction of the left ventricle, especially regional wall motion abnormalities and reduced ejection fraction $(16,45)$. Patients with increased levels of BNP should not be subjected to much fluid overload based on triple $\mathrm{H}$ therapy. In our results the mean value of proBNP was $1928 \mathrm{pg} / \mathrm{ml}$, mostly due to the excessively elevated values in two cases above 17.000 and $19.000 \mathrm{pg} / \mathrm{ml}$. However the mean serum levels of pro-BNP decreased excessively after 5 days, but only one patient developed a severe heart incident, although the overall levels of BNP in the patient cohort remained elevated.
The increased levels of BNP are strongly and independently associated with cerebral infarction, and the association is most pronounced in patients without angiographic vasospasm (31). BNP rises gradually over two days and returns to normal within a week after $\mathrm{SAH}$. Its release is associated with myocardial necrosis, but is unrelated to elevation of left ventricular assessed by echocardiography (17).

\section{CONCLUSION}

In the acute phase after $\mathrm{SAH}$ onset a meticulous monitoring of different serum components is of great importance, because significant fluctuations and deviations from the reference values might occur. This study showed a significant decrease in the serum level of $L D L$ and $\mathrm{HDL}$, while TG values were moderately heightened. There were no serious disturbances of fluid and electrolyte balance. High levels of BNP did not correlate with the coexistence of severe cardiac complications.

Routine monitoring of lipid profile and statin administration at the early stage of $\mathrm{SAH}$ is recommended.

\section{REFERENCES}

1. Banki N, Kopelnik A, Tung P, Lawton MT, Gress D, Drew B, Dae M, Foster E, Parmley W, Zaroff J: Prospective analysis of prevalence, distribution, and rate of recovery of left ventricular systolic dysfunction in patients with subarachnoid hemorrhage. J Neurosurg 105: 15-20,2006

2. Bennani SL, Abouqal R, Zeggwagh AA, Madani N, Abidi K, Zekraoui A, Kerkeb O: Incidence, causes and prognostic factors of hyponatremia in intensive care. Rev Med Interne 24: 224-229, 2003

3. Bolli R, Marbán E: Molecular and cellular mechanisms of myocardial stunning. Physiol Rev 79: 609-634, 1999

4. Canhão P, Pinto AN, Ferro H, Ferro JM: Smoking and aneurysmal subarachnoid haemorrhage: A case-control study. J Cardiovasc Risk 1:155-158,1994

5. Coombes EJ, Shakespeare PG, Bastone GF: Lipoprotein changes after burn injury in man. J Trauma 20:971-975, 1980

6. Edwards JE, Moore RA: Statins in hypercholesterolaemia: A dose-specific meta-analysis of lipid changes in randomised, double blind trials. BMC Fam Pract 4:18, 2003

7. Ekelund A, Reinstrup P, Ryding E, Andersson AM, Molund T, Kristiansson KA, Romner B, Brandt L, Saveland H: Effects of iso- and hypervolemic hemodilution on regional cerebral blood flow and oxygen delivery for patients with vasospasm after aneurysmal subarachnoid hemorrhage. Acta Neurochir (Wien) 144: 703-712, 2002

8. Fisher LA, Ko N, Miss J, Tung PP, Kopelnik A, Banki NM, Gardner D, Smith WS, Lawton MT, Zaroff JG: Hypernatremia predicts adverse cardiovascular and neurological outcomes after SAH. Neurocrit Care 5(3):180-185, 2006

9. Fountas KN, Tasiou A, Kapsalaki EZ, Paterakis KN, Grigorian $A A$, Lee GP, Robinson JS Jr: Serum and cerebrospinal fluid C-reactive protein levels as predictors of vasospasm in aneurysmal subarachnoid hemorrhage. Clinical article. Neurosurg Focus 26(5): E22, 2009 
10. Hasan D, Wijdicks EF, Vermeulen M: Hyponatremia is associated with cerebral ischemia in patients with aneurismal subarachnoid hemorrhage. Ann Neurol 27:106-108, 1990

11. Iso $H$, Jacobs DR, Wentworth D, Neaton JD, Cohen JD: Serum cholesterol levels and six year mortality from stroke in 350,977 men screened for the multiple risk factor intervention trial. $\mathrm{N}$ Engl J Med 320:904-910, 1989

12. Juvela S, Kuhmonen J, Siironen J: C-reactive protein as predictor for poor outcome after aneurysmal subarachnoid haemorrhage. Acta Neurochir (Wien) 154(3):397-404, 2012

13. Kamolz LP, Andel H, Mittlböck M, Winter W, Haslik W, Meissl G, Frey M: Serum cholesterol and triglycerides: Potential role in mortality prediction. Burns 29: 810-815, 2003

14. Luscher MS, Thygesen K, Ravkilde J, Heickendorff L: Applicability of cardiac troponin $\mathrm{T}$ and I for early risk stratification in unstable coronary artery disease. TRIM Study Group. Thrombin inhibition in myocardial ischemia. Circulation 96:2578- 2585,1997

15. Mandal AK, Saklayen MG, Hillman NM, Markert RJ: Predictive factors for high mortality in hypernatremic patients. Am J Emerg Med 15:130-132, 1997

16. McGirt MJ, Blessing R, Nimjee SM, Friedman AH, Alexander MJ, Laskowitz DT, Lynch JR: Correlation of serum brain natriuretic peptide with hyponatremia and delayed ischemic neurological deficits after subarachnoid hemorrhage. Neurosurgery 54:1369-1373, 2004

17. Meaudre $E$, Jego $C$, Kenane $N$, Montcriol A, Boret $H$, Goutorbe P, Habib G, Palmier B: B-type natriuretic peptide release and left ventricular filling pressure assessed by echocardiographic study after subarachnoid hemorrhage: A prospective study in non-cardiac patients. Crit Care 13(3):R76, 2009

18. Millar JS, Ky B, Wolfe ML, Pruscino L, Baer A, Rader DJ: Short-term treatment with high-dose atorvastatin reduces LDL cholesterol but shows no anti-inflammatory effects in normolipidemic subjects with normal CRP levels. Clin Transl Sci 3(4):140-146, 2010

19. Murphy AM, Kögler $H$, Marbán E: A mouse model of myocardial stunning. Mol Med Today 6: 330-331, 2000

20. Naidech AM, Jovanovic B, Wartenberg KE, Parra A, Ostapkovich $\mathrm{N}$, Connolly ES, Mayer SA, Commichau C: Higher hemoglobin is associated with improved outcome after subarachnoid hemorrhage. Crit Care Med 35:2383-2389, 2007

21. Naidech AM, Kreiter KT, Janjua N, Ostapkovich ND, Parra A, Commichau C, Fitzsimmons BF, Connolly ES, Mayer SA: Cardiac troponin elevation, cardiovascular morbidity, and outcome after subarachnoid hemorrhage. Circulation 112: 2851-2856, 2005

22. Nakamura T, Okuchi $K$, Matsuyama T, Fukushima $H$, Seki T, Konobu T, Nishio K: Clinical significance of elevated natriuretic peptide levels and cardiopulmonary parameters after subarachnoid hemorrhage. Neurol Med Chir (Tokyo) 49(5):185-191, 2009
23. Nyika D Kruyt, Geert Jan Biessels, J Hans DeVries, Merel J A Luitse, Marinus Vermeulen, Gabriel J E Rinkel, W Peter Vandertop, Roos YB: Hyperglycemia in aneurysmal subarachnoid hemorrhage: A potentially modifiable risk factor for poor outcome. J Cereb Blood Flow Metab 30(9): 1577-1587, 2010

24. Parekh N, Venkatesh B, Cross D, Leditschke A, Atherton J, Miles W, Winning A, Clague A, Rickard C: Cardiac troponin I predicts myocardial dysfunction in aneurysmal subarachnoid hemorrhage. J Am Coll Cardiol 36:1328-1335, 2000

25. Plenge JK, Hernandez TL, Weil KM, Poirier P, Grunwald GK, Marcovina SM, Eckel RH: Simvastatin lowers C-reactive protein within 14 days: An effect independent of low-density lipoprotein cholesterol reduction. Circulation 106(12): 1447-1452, 2002

26. Sabri M, Macdonald RL: Statins: A potential therapeutic addition to treatment for aneurysmal subarachnoid haemorrhage? World Neurosurg 73:646-653, 2010

27. Sahib AS: Dyslipidemia after burn injury: A potential therapeutic target. Asian J Pharm Clin Res 4(4): 34-36, 2011

28. Sandvei MS, Lindekleiv $H$, Romundstad PR, Müller TB, Vatten LJ, Ingebrigtsen T, Njølstad I, Mathiesen EB, Vik A: Risk factors for aneurysmal subarachnoid hemorrhage - BMI and serum lipids: 11-year follow-up of the HUNT and the Troms $\varnothing$ Study in Norway. Acta Neurol Scand 125(6):382-388, 2012

29. Smith MJ, Le Roux PD, Elliott JP, Winn HR: Blood transfusion and increased risk for vasospasm and poor outcome after subarachnoid hemorrhage. J Neurosurg 101:1-7, 2004

30. Solomon RA, Fink ME, Lennihan L: Early aneurysm surgery and prophylactic hypervolemic hypertensive therapy for the treatment of aneurysmal subarachnoid hemorrhage. Neurosurgery 23: 699-704, 1988

31. Taub PR, Fields JD, Wu AH, Miss JC, Lawton MT, Smith WS, Young WL, Zaroff JG, Ko NU: Elevated BNP is associated with vasospasm-independent cerebral infarction following aneurysmal subarachnoid hemorrhage. Neurocrit Care 15(1):13-18, 2011

32. Teunissen LL, Rinkel GJ, Algra A, van Gijn J: Risk factors for subarachnoid hemorrhage: A systematic review. Stroke 27(3): 544-549, 1996

33. Tokuda Y, Stein GH J: Serum lipids as protective factors for subarachnoid hemorrhage. Clin Neurosci 12(5):538-541, 2005

34. Tomida M, Muraki M, Uemura K, Yamasaki K: Plasma concentrations of brain natriuretic peptide in patients with subarachnoid hemorrhage. Stroke 29:1584 -1587,1998

35. Tseng MY: Participants in the international multidisciplinary consensus conference on the Critical Care Management of Subarachnoid Hemorrhage. Summary of evidence on immediate statins therapy following aneurysmal subarachnoid haemorrhage. Neurocrit Care 15(2):298-301, 2011

36. Tung PP, Olmsted E, Kopelnik A, Banki NM, Drew BJ, Ko N, Lawton MT, Smith W, Foster E, Young WL, Zaroff JG: Plasma B-type natriuretic peptide levels are associated with early cardiac dysfunction after subarachnoid hemorrhage. Stroke $36: 1567-1571,2005$ 
37. Qureshi Al, Suri MF, Sung GY, Straw RN, Yahia AM, Saad M, Guterman LR, Hopkins LN: Prognostic significance of hypernatremia and hyponatremia among patients with aneurysmal subarachnoid hemorrhage. Neurosurgery 50:749-755, 2002

38. Vergouwen MD, de Haan RJ, Vermeulen M, Roos YB: Effect of statin treatment on vasospasm, delayed cerebral ischemia, and functional outcome in patients with aneurysmal subarachnoid hemorrhage: A systematic review and metaanalysis update. Stroke 41: e47-52, 2010

39. Wartenberg KE, Mayer SA: Medical complications after subarachnoid hemorrhage: New strategies for prevention and management. Curr Opin Crit Care 12: 78-84, 2006

40. Wartenberg KE, Schmidt JM, Claassen J, Temes RE, Frontera JA, Ostapkovich N, Parra A, Connolly ES, Mayer SA: Impact of medical complications on outcome after subarachnoid hemorrhage. Crit Care Med 34(3):617-623, 2006
41. Weng TC, Yang YH, Lin SJ, Tai SH: A systematic review and meta-analysis on the therapeutic equivalence of statins. J Clin Pharm Ther 35(2):139-151, 2010

42. Wong GK, Poon WS, Chan MT, Boet R, Gin T, Ng SC, Zee BC; IMASH Investigators: Intravenous magnesium sulphate for aneurysmal subarachnoid hemorrhage (IMASH): A randomized, double-blinded, placebo-controlled, multicenter phase III trial. Stroke 41:921-926, 2010

43. Wong GK, Poon WS: Magnesium sulphate for aneurysmal subarachnoid hemorrhage: Why, how, and current controversy. Acta Neurochir Suppl 115:45-48, 2013

44. Yano K, Reed DM, MacLean CJ: Serum cholesterol and hemorrhagic stroke in the Honolulu Heart Program. Stroke 20(11):1460-1465, 1989

45. Yarlagadda S, Rajendran P, Miss JC, Banki NM, Kopelnik A, Wu AH, Ko N, Gelb AW, Lawton MT, Smith WS, Young WL, Zaroff JG: Cardiovascular predictors of in-patient mortality after subarachnoid hemorrhage. Neurocrit Care 5:102-107, 2006 